\title{
RESPONSE OF IRRIGATED WHEAT CULTIVARS TO DIFFERENT NITROGEN RATES AND SOURCES ${ }^{(1)}$
}

\author{
Marcelo Carvalho Minhoto Teixeira Filho(2), Salatiér Buzetti ${ }^{(3)}$, \\ Marcelo Andreotti ${ }^{(4)}$, Marco Eustáquio de Sá(5), Orivaldo Arf ${ }^{(5)} \&$ \\ Márcio Mohamed Megda ${ }^{(6)}$
}

\begin{abstract}
SUMMARY
High wheat yields require good $\mathrm{N}$ fertilization management. The objective of this study was to evaluate the effects of different $N$ applications at sowing using Entec ( $N$ source with nitrification inhibitor) and urea (traditional $N$ source) at covering, on four wheat cultivars. The experiment was conducted in a randomized block design in a factorial scheme, with four replications, at the Experimental Station of the Faculdade de Engenharia de Ilha Solteira - UNESP, on a dystrophic, epi-eutrophic alic Red Latosol with loamy texture, formerly under savannah vegetation. Four $\mathrm{N}$ rates $\left(0,60,120\right.$, and $\left.180 \mathrm{~kg} \mathrm{ha}^{-1}\right)$ were tested, applied at sowing in the case of Entec and top-dressed 40 days after plant emergence in the case of urea, and the four wheat cultivars $\mathrm{E} 21, \mathrm{E} 22, \mathrm{E} 42$, and IAC 370 . The yield of the wheat cultivars E 21 and E 42 was highest. Plant height and lodging index of cultivar E 22 were greatest, with consequently lowest grain yield. There was no significant difference between Entec (applied at sowing) and urea (top-dressed) in terms of grain yield and yield components. Nevertheless, urea resulted in a higher $\mathrm{N}$ leaf content, and Entec in a larger number of undeveloped spikelets. High nitrogen rates influenced the hectoliter mass negatively, affecting wheat grain quality. Grain yield increased under $\mathrm{N}$ rates of up to $82 \mathrm{~kg} \mathrm{ha}^{-1} \mathrm{~N}$, through Entec applied at sowing or top-dressed urea.
\end{abstract}

Index terms: Triticum aestivum L., savannah soil, Entec, urea, grain yield, yield components.

(1) Recebido para publicação em agosto de 2008 e aprovado em maio de 2009.

(2) Doutorando do Programa de Pós-Graduação em Agronomia, Faculdade de Engenharia, Universidade Estadual Paulista UNESP. Campus de Ilha Solteira. Av. Brasil 56, CEP 15385-000 Ilha Solteira (SP). Bolsista FAPESP. E-mail: mcmtf@yahoo.com.br

(3) Professor Titular do do Departamento de Fitossanidade, Engenharia Rural e Solos, Faculdade de Engenharia, UNESP. Bolsista em produtividade pelo CNPq. E-mail: sbuzetti@agr.feis.unesp.br

${ }^{(4)}$ Professor Doutor do Departamento de Fitossanidade, Engenharia Rural e Solos, Faculdade de Engenharia, UNESP. E-mail: dreotti@agr.feis.unesp.br

${ }^{(5)}$ Professores Titulares do Departamento de Fitotecnia, Sócio Economia e Sociologia Rural, Faculdade de Engenharia, UNESP. E-mails: mesa@agr.feis.unesp.br; arf@agr.feis.unesp.br

(6) Mestrando em Ciência do Solo, Escola Superior de Agricultura Luiz de Queiroz - ESALQ/USP. CEP 13418-900 Piracicaba (SP). E-mail: marcio_agr@yahoo.com.br 


\title{
RESUMO: RESPOSTA DE CULTIVARES DE TRIGO IRRIGADO A DIFERENTES DOSES E FONTES DE NITROGÊEIO
}

\begin{abstract}
Altas produtividades de trigo requerem um bom manejo da adubação nitrogenada. $O$ objetivo deste trabalho foi avaliar os efeitos de diferentes doses de nitrogênio na semeadura usando o Entec (fonte de $N$ com inibidor de nitrificação), ou em cobertura, utilizando a ureia, em quatro cultivares de trigo. O experimento foi desenvolvido em área experimental pertencente à Faculdade de Engenharia de Ilha Solteira - UNESP, em um Latossolo Vermelho distrófico epieutrófico álico textura argilosa, o qual foi nativamente ocupado por vegetação de Cerrado. $O$ delineamento estatístico foi o de blocos ao acaso, com quatro doses de $N(0,60,120$ e $180 \mathrm{~kg} \mathrm{ha}^{-1}$ ) na semeadura, usando o Entec, ou em cobertura aos 40 dias (início do alongamento), empregando a ureia e os cultivares E 21, E 22, E 42 e IAC 370, em quatro repetições. Os cultivares de trigo mais produtivos foram o $E 21$ e o $E$ 42. O cultivar $E 22$ apresentou maior altura de plantas e altas notas de acamamento, com consequente menor produtividade de grãos. Não houve diferença significativa entre o Entec (aplicado na semeadura) e a ureia (aplicada em cobertura) para produtividade de grãos e para nenhuma das outras avaliações, porém a ureia proporcionou maior teor de $N$ foliar, e o Entec, maior número de espiguetas não desenvolvidas. O incremento das doses de Ninfluenciou negativamente a massa hectolitrica, alterando assim a qualidade dos grãos de trigo. ON aumentou a produtividade de grãos de trigo até a dose de $82 \mathrm{~kg} \mathrm{ha}^{-1}$ de $\mathrm{N}$, usando Entec aplicado na semeadura ou ureia aplicada em cobertura.
\end{abstract}

Termos de indexação: Triticum aestivum L., Cerrado, Entec, ureia, produtividade de grãos, componentes da produção.

\section{INTRODUCTION}

Nitrogen fertilization for wheat crops is essential to obtain high yields; however, it requires careful use, with regard to the application time and application rates. Low rates restrict yields and high rates can lead to lodging, making harvest work difficult and reducing yields. High rates are also harmful to the environment, due to nitrate leaching into the ground water, and higher costs for the growers. The study of different $\mathrm{N}$ sources is also fundamental, since the different $\mathrm{N}$ fertilizers applied to the soil perform differently, in terms of losses.

Urea is the most used $\mathrm{N}$ fertilizer in Brazil due to its advantages in costs, easy production and final cost for the producer. From the agricultural point of view, urea is a serious limiting factor when applied to the soil surface, due to the loss chances through $\mathrm{NH}_{3}$ volatization (Koerlliker \& Kissel, 1988). In many soil types the losses of applied N exceed 50 \% (Cantarella et al., 1999).

Ammonium sulphonitrate (Entec), which contains $26 \%$ total $\mathrm{N}$ and $12 \% \mathrm{~S}$, mostly in the form of ammonia (18.5\% ammonium and $7.5 \%$ nitric form), has recently been released to enhance the efficiency of $\mathrm{N}$ fertilizers. It contains DMPP (3,4 dimethyl pyrazolphosphate) which participates in the nitrification process. DMPP is derived from the pyrazol group (Los Fertilizantes..., 2006). The nitrification inhibition process is interesting, because it maintains $\mathrm{N}$ in the form of $\mathrm{NH}_{4}{ }^{+}$, which is more easily assimilated by plants, available for a longer time and $\mathrm{N}$ losses by leaching are lower, so even fertilizer $\mathrm{N}$ can be better exploited.

However, there are few studies on wheat response to $\mathrm{N}$ fertilization and it must be studied under specific conditions, especially in the savannah area where the use of irrigation is necessary in no season crop period. For this reason, the objective of this study was to evaluate the effect of different $\mathrm{N}$ rates at sowing or as top dressing $\left(0,60,120\right.$, and $\left.180 \mathrm{~kg} \mathrm{ha}^{-1}\right)$ using Entec ( $\mathrm{N}$ source with nitrification inhibitor) or urea, for four irrigated wheat cultivars, in the savannah area.

\section{MATERIAL AND METHODS}

The experiment was carried out in an experimental area of the Universidade Estadual Paulista (UNESP), in Selvíria, Mato Grosso do Sul (long. $51^{\circ} 22^{\prime} \mathrm{W}$, lat. $20^{\circ} 22^{\prime} \mathrm{S}, 335 \mathrm{~m}$ asl). The soil was classified as an epi-eutrophic alic dystrophic Red Latosol loamy texture, according to the designation by the new Brazilian Soil Classification System (Embrapa, 2006), formerly under savannah vegetation and then growing annual crops for over 25 years. In the annual mean, the temperature is $23.5^{\circ} \mathrm{C}$, rainfall $1,370 \mathrm{~mm}$ and relative humidity between 70 and $80 \%$ (Figure 1).

The soil chemical properties were evaluated prior to the experiment, according to the method of Raij \& Quaggio (1983), as follows: $27 \mathrm{mg} \mathrm{dm}^{-3} \mathrm{P}$ (resin); 


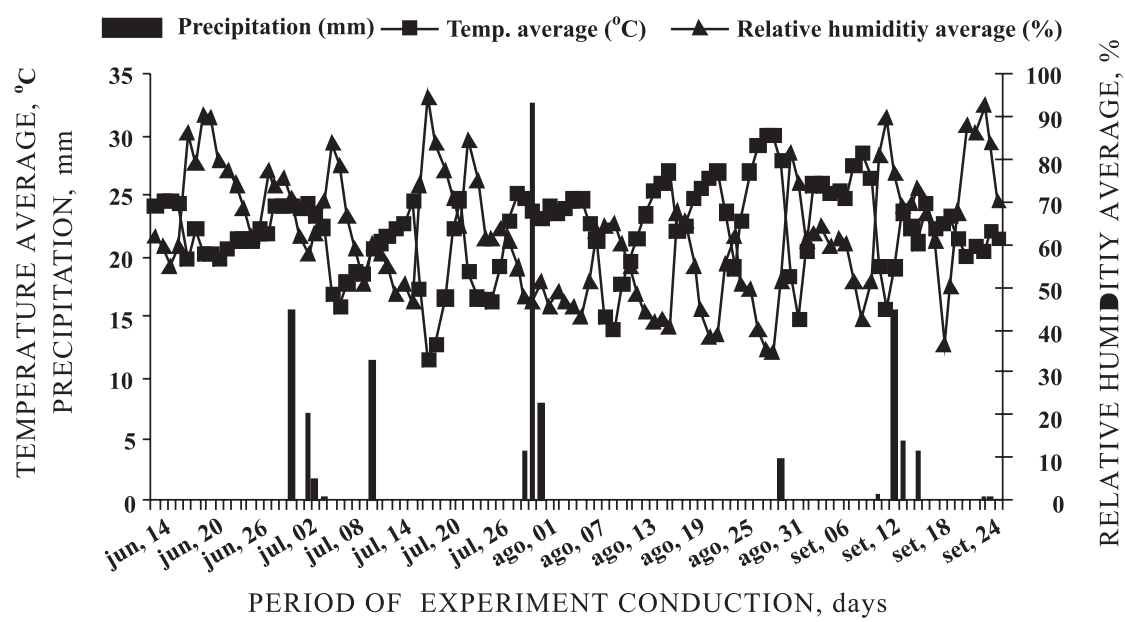

Figure 1. Pluvial precipitation, average temperature and air relative humiditiy, during the experiment. Selvíria - MS, 2005.

$31 \mathrm{~g} \mathrm{dm}^{-3}$ organic matter; pH $5.9\left(\mathrm{CaCl}_{2}\right) ; \mathrm{K}, \mathrm{Ca}^{2+}$, $\mathrm{Mg}^{2+}, \mathrm{H}+\mathrm{Al}=3.0 ; 49.0 ; 21.0 ;$ and $20.0 \mathrm{mmol}_{\mathrm{c}} \mathrm{dm}^{-3}$, respectively, and $78 \%$ base saturation.

The soil was tilled in the first week of June 2005, by plowing and harrowing, to sow the wheat cultivars E 21, E 22, E 42, and IAC 370 on July 14, 2005, with a drill. After sowing, the area was irrigated by a center-pivot sprinkler system with a water application depth of approximately $14 \mathrm{~mm}$ for seed germination. Emergence occurred six days after sowing.

As basic fertilization, $250 \mathrm{~kg} \mathrm{ha}^{-1}$ of the compound fertilizer 04-30-10 was used. Before sowing, the seeds were treated with carboxin + thiram $(60+60 \mathrm{~g}$ a.i. $100 \mathrm{~kg}^{-1}$ seeds). Water was supplied by a center-pivot sprinkler irrigation system, and weeds were controlled by the application of the post-emergence herbicide metsulfuron methyl (3.0 $\mathrm{g} \mathrm{ha}^{-1}$ a.i.).

A randomized block experimental design was used in a factorial scheme $(4 \times 2 \times 4)$, with four $\mathrm{N}$ rates $(0$, 60,120 , and $\left.180 \mathrm{~kg} \mathrm{ha}^{-1}\right)$. Nitrogen was applied as Entec - a fertilizer with nitrification inhibitor, at sowing or as urea, as top dressing, on the $40^{\text {th }}$ day after emergence, to the four wheat cultivars. The plots were $5 \mathrm{~m}$ long, contaning 5 rows spaced $0.17 \mathrm{~m}$ apart with 80 seeds per meter. After emergence, $\mathrm{N}$ top dressing was applied between rows after 40 , the flag leaves were sampled after 68 and the plants harvested manually after 105 days.

The following variables were evaluated: (a) $\mathrm{N}$ content in the flag leaf, collected at the beginning of flowering (Cantarella et al., 1997); (b) plant height at maturation, defined as the distance $(\mathrm{cm})$ from ground level to the tip of the ears, excluding the awns, of 10 plants per plot); (c) count of number of ears per meter; (d) 10 wheat spikelets were harvested per experimental plot, to evaluate ears and grains, concerning the ear length (defined as the distance $(\mathrm{cm})$ from the raquis basis to the tip of the ear, excluding the awns), the number of undeveloped spikelets, number of spikelets per ear, total number of grains per ear, total number of grains per ear and number of grains per spikelet; (e) lodging level, determined by visual evaluations during maturation, based on the following ranking: 1: 0 to $5 \%$; 2 : 6 to $25 \%$; 3 : 26 to $50 \%$; $4: 51$ to $75 \%$ and 5: over $75 \%$ lodged plants; (f) hectoliter mass, corresponding to the grain mass in a volume of $100 \mathrm{~L}$, determined in a scale of $0.25 \mathrm{~L}$ with correction of the grain moisture level to $13 \%$ (wet basis); (g) mass of 100 grains, determined on $0.01 \mathrm{~g}$ precision scales, with grain moisture corrected to $13 \%$ (wet basis); (h) grain yield, determined by collecting plants from the three central rows of each plot. After mechanical threshing, grains were quantified and the data translated into $\mathrm{kg} \mathrm{ha}^{-1}$ at $13 \%$ moisture (wet basis).

Analysis of variance was used and the means were compared by the Tukey test at $5 \%$ for the effect of $\mathrm{N}$ sources and cultivars, and adjusted to regression equations for the effect of $\mathrm{N}$ rates.

\section{RESULTS AND DISCUSSION}

No significant effect of $\mathrm{N}$ rates was verified in the experiment for any of the evaluations concerning the ear traits (ear length, number of undeveloped spikelets, number of spikelets per ear, number of grains per ear and number of grains per spikelet), indicating that these evaluations depended on the genetic potential of the crop, which was limited by N (Freitas et al., 1995). Pettinelli Neto et al. (2002) did not observe an effect of $\mathrm{N}$ on the number of grains per ear either. Nevertheless, Bredemer \& Mundstock (2001) verified an increase in the number of spikelets and number of grains per ear, when $\mathrm{N}$ was applied at the third leaf stage. Teixeira Filho et al. (2007) also studied the 
response of irrigated wheat cultivars in the savannah region to differents topdressed $\mathrm{N}$ rates $(0,30,60,90$, and $120 \mathrm{~kg} \mathrm{ha}^{-1}$ ) and showed that the $\mathrm{N}$ rates significantly influenced the number of grains per ear and the reponse fitted to a quadratic function. These differences were due to the different cultivars used, soil and climate conditions, $\mathrm{N}$ application time and crop management. Regarding the $\mathrm{N}$ sources, only the number of undeveloped spikelets was significantly influenced (Table 1). Regarding the cultivars, the effect was significant for all variables related to the ear characteristics (Table 1). This indicated genetic variability in the studied cultivars.

Plant height was significantly influenced by the $\mathrm{N}$ sources and cultivars, unlike the $\mathrm{N}$ rates (Table 1 ). However, Zagonel et al. (2002) investigated topdressed $\mathrm{N}$ rates $\left(0,45,90\right.$, and $\left.135 \mathrm{~kg} \mathrm{ha}^{-1}\right)$ and different plant densities with and without growth regulator for wheat and observed an increase in plant height in response to increased $\mathrm{N}$ rates.

Of the cultivars, E 21 performed best, since the results for ear length, number of spikelets per ear, number of grains per ear, number of grains per spikelet and number of undeveloped spikelets were better than for the other cultivars; results were worst for cultivar E 22 (Table 2).

During maturation, plant height was influenced by $\mathrm{N}$ rates in a quadratic form; maximum height was reached with an estimated $\mathrm{N}$ application of $98 \mathrm{~kg} \mathrm{ha}^{-1}$ (Table 2). Of the cultivars, results for plant height were best in E 22, exceeding the other cultivars by a mean of $14.37 \mathrm{~cm}$ (Table 2). This explains why the lodging index of E 22 was highest (Table 3), and the

Table 1. Mean squares, significances, overall means and coefficient of variation regarding the ear length (L. EARS), number of undeveloped spikelets (N.D. SPIK.), number of spikelets per ear (SPIK./EAR), number of grains per ear (G/EAR), number of grains per spikelet (G/SPIK.) and plant height (P.H.)

\begin{tabular}{|c|c|c|c|c|c|c|}
\hline \multirow{2}{*}{ Causes of variation } & \multicolumn{6}{|c|}{ MS } \\
\hline & L. EARS & N.D. SPIK. & SPIK./EAR & G/EAR & G/SPIK. & P.H. \\
\hline Cultivar (C) & $76.708^{* *}$ & $15.666^{* *}$ & $83.826^{* *}$ & $1426.967 * *$ & $1.095^{*}$ & $1711.258^{* *}$ \\
\hline N Sources (S) & $0.097 \mathrm{~ns}$ & $4.043^{* *}$ & $1.234 \mathrm{~ns}$ & $0.488 \mathrm{~ns}$ & $0.028 \mathrm{~ns}$ & $73.508^{*}$ \\
\hline N Doses (D) & $0.239 \mathrm{~ns}$ & $0.097 \mathrm{~ns}$ & $1.853 \mathrm{~ns}$ & $2.904 \mathrm{~ns}$ & $0.094 \mathrm{~ns}$ & $47.883 \mathrm{~ns}$ \\
\hline Blocks & $0.053 \mathrm{~ns}$ & $0.041 \mathrm{~ns}$ & $0.999 \mathrm{~ns}$ & $21.067 \mathrm{~ns}$ & $0.018 \mathrm{~ns}$ & $76.591^{* *}$ \\
\hline $\mathrm{C} \times \mathrm{S}$ & $0.110 \mathrm{~ns}$ & $0.141 \mathrm{~ns}$ & $2.883 \mathrm{~ns}$ & $19.209 \mathrm{~ns}$ & $0.011 \mathrm{~ns}$ & $21.008 \mathrm{~ns}$ \\
\hline $\mathrm{C} \times \mathrm{D}$ & $0.561 \mathrm{~ns}$ & $0.335 \mathrm{~ns}$ & $0.755 \mathrm{~ns}$ & $14.815 \mathrm{~ns}$ & $0.032 \mathrm{~ns}$ & $16.161 \mathrm{~ns}$ \\
\hline $\mathrm{S} \times \mathrm{D}$ & $1.273 \mathrm{~ns}$ & $0.184 \mathrm{~ns}$ & $3.226 \mathrm{~ns}$ & $9.914 \mathrm{~ns}$ & $0.094 \mathrm{~ns}$ & $38.924 \mathrm{~ns}$ \\
\hline $\mathrm{C} \times \mathrm{S} \times \mathrm{D}$ & $0.587 \mathrm{~ns}$ & $0.072 \mathrm{~ns}$ & $0.665 \mathrm{~ns}$ & $12.034 \mathrm{~ns}$ & $0.056 \mathrm{~ns}$ & $9.174 \mathrm{~ns}$ \\
\hline Residue & 0.549 & 0.252 & 1.044 & 20.590 & 0.047 & 18.844 \\
\hline Overall means & 9.62 & 2.16 & 16.92 & 42.90 & 2.53 & 93.01 \\
\hline $\mathrm{CV}(\%)$ & 7.70 & 23.19 & 6.04 & 10.58 & 8.58 & 4.67 \\
\hline
\end{tabular}

**: significant $\mathrm{p}<0.01 ; *$ : significant $0.01<\mathrm{p}<0.05 ; \mathrm{ns}$ : not significant.

Table 2. Means, Tukey test and regression equations regarding ear length (L. EARS), number of undeveloped spikelets (N.D. SPIK.), number of spikelets per ear (SPIK./EAR), number of grains per ear (G/EAR), number of grains per spikelet (G/SPIK.) and plant height (P.H.)

\begin{tabular}{|c|c|c|c|c|c|c|}
\hline & L. EARS & N.D. SPIK. & SPIK./EAR & G/EAR & G/SPIK. & P.H. \\
\hline & $\mathrm{cm}$ & & & & & $\mathrm{cm}$ \\
\hline Cultivar - E21 & $11.17 \mathrm{a}$ & $1.41 \mathrm{~b}$ & $19.24 \mathrm{a}$ & $51.28 \mathrm{a}$ & $2.66 \mathrm{a}$ & $91.25 \mathrm{~b}$ \\
\hline E 22 & $7.73 \mathrm{~b}$ & $3.07 \mathrm{a}$ & $15.75 \mathrm{c}$ & $35.75 \mathrm{~b}$ & $2.27 \mathrm{c}$ & $103.78 \mathrm{a}$ \\
\hline E 42 & $10.55 \mathrm{~b}$ & $1.89 \mathrm{c}$ & $16.80 \mathrm{~b}$ & $44.69 \mathrm{~b}$ & $2.66 \mathrm{a}$ & $89.06 \mathrm{bc}$ \\
\hline IAC 370 & $9.03 \mathrm{c}$ & $2.29 \mathrm{~b}$ & $15.88 \mathrm{c}$ & $39.87 \mathrm{c}$ & $2.51 \mathrm{~b}$ & $87.94 \mathrm{c}$ \\
\hline N Sources - Entec & $9.65 \mathrm{a}$ & $2.34 \mathrm{a}$ & $15.82 \mathrm{a}$ & $42.96 \mathrm{a}$ & $2.51 \mathrm{a}$ & $93.77 \mathrm{a}$ \\
\hline Urea & $9.59 \mathrm{a}$ & $1.99 \mathrm{~b}$ & $15.84 \mathrm{a}$ & $42.84 \mathrm{a}$ & $2.54 \mathrm{a}$ & $92.25 \mathrm{a}$ \\
\hline N Doses - 0 & 9.58 & 2.20 & 16.64 & 42.22 & 2.58 & $94.31^{(1)}$ \\
\hline$\left(\mathrm{kg} \mathrm{ha}^{-1}\right) 60$ & 9.54 & 2.16 & 17.09 & 42.80 & 2.49 & 92.44 \\
\hline 120 & 9.62 & 2.09 & 16.79 & 43.04 & 2.56 & 91.59 \\
\hline 180 & 9.74 & 2.21 & 17.15 & 42.53 & 2.47 & 93.69 \\
\hline
\end{tabular}

(1) $\hat{y}=94.4078-0.0541 \mathrm{x}+0.0003^{* *} \mathrm{x}^{2}\left(\mathrm{R}^{2}=0.96\right.$ and maximum P.H. $=98 \mathrm{~kg} \mathrm{ha}^{-1}$ of $\left.\mathrm{N}\right)$. Means followed by the same letters, in the column, do not differ according to the Tukey test, at $5 \%$. **: significant $\mathrm{p}<0.01$. 
grain yield consequently low (Table 5). According to Cruz et al. (2000), when environmental factors are optimized by fertilization and irrigation, lodging becomes one of the main difficulties for the genotypes to reach maximum yields.

No lodging was observed for the cultivars E 21 and IAC 370, even at the highest $\mathrm{N}$ rates. This was due to the lack of effect of the $\mathrm{N}$ on plant height of these cultivars. Nevertheless, lodging of the cultivars E 22 and $\mathrm{E} 42$, and that the lodging indexes were higher in the Entec than the urea treatments, at the same $\mathrm{N}$ rates (Table 3). This was probably due to the initial $\mathrm{N}$ supply via Entec, since urea was applied as top dressing.

The $\mathrm{N}$ leaf content at flowering was significantly influenced by the $\mathrm{N}$ sources, but there was no significant effect for $\mathrm{N}$ rates and cultivars (Table 4). However, in table 5, the higher results than the appropriate $\mathrm{N}$ rates, described by Cantarella et al. (1997), can be observed (20 to $34 \mathrm{~g}^{\text {of }} \mathrm{N} \mathrm{kg}^{-1}$ of dry matter) (Table 5).

The urea source resulted in higher $\mathrm{N}$ leaf contents at flowering than Entec in the wheat plants, regardless of the cultivar (Table 5). This was probably due to the fact that urea was applied as top dressing on the $40^{\text {th }}$ day after emergence (beginning of elongation), while Entec was applied at sowing; therefore, the urea top dressing resulted in a better $\mathrm{N}$ availability to plants at flowering. However, the total Entec application at sowing resulted in a high $\mathrm{N}$ level in the plant, probably due to lower $\mathrm{N}$ losses (leaching and denitrification), resulting in a longer $\mathrm{N}$ permanence in the soil and greater $\mathrm{N}$ availability to the plants. According to Los Fertilizantes... (2006), this fertilizer has DMPP molecules that participate in nitrification inhibition.

Table 4 shows a significant effect of the cultivars on the number of ears per meter, hectoliter mass, mass of 100 grains and grain yield. Nevertheless, the $\mathrm{N}$ sources did not influence these evaluations. This lack of response to the $\mathrm{N}$ sources was probably due to the fact that low rainfall was registered in the crop period (Figure 1), at the time the experiment was conducted. And that, soon after application, the plots were irrigated, thereby decreasing volatilization losses, especially of urea. According to Cantarella et al. (1999), the urea $\mathrm{NH}_{3}$ volatilization losses from different soil types can exceed $50 \%$ of the applied $\mathrm{N}$.

Regarding the $\mathrm{N}$ rates, there were no significant effects for number of ears per meter and mass of 100 grains (Table 4). Zagonel et al. (2002) and Soares Sobrinho (1999) observed no N effect on the mass of 1000 grains either. On the other hand, Teixeira Filho et al. (2007) and Zagonel et al. (2002) observed increases in the number of ears per meter, with topdressed $\mathrm{N}$ application using urea.

The $\mathrm{N}$ rates did not significantly influence hectoliter mass and grain yield (Table 4). Bredemier \& Mundstock (2001), Vieira et al. (1995), Freitas et al. (1994, 1995), Silva \& Goto (1991), Coqueiro et al. (1972), and Zagonel et al. (2002) observed no N effect on crop yield either. However, Pettinelli Neto et al. (2002) and Silva (1991) observed no N effect on crop yield due to the residual $\mathrm{N}$ from soybean, which had been grown in the area for many years. The same result was observed by Pottker et al. (1984), but due to adverse climate conditions, they did not observe the effect of $\mathrm{N}$ application on crop yield.

Regarding the number of ears per meter, the cultivars E 21 and the E 22 performed better than the others (Table 5). Concerning hectoliter mass, the indexes of cultivar E 21 were lowest. The mass of 100 grains was highest for cultivar E 22. The cultivars with best yields were E 21 and E 42, which differed statistically from E 22 and from IAC 370 (Table 5). Regarding the $\mathrm{N}$ sources, there was no significant difference between Entec (applied at sowing) and urea (topdressed) for grain yield and yield components (Table 5). This result of anticipating $\mathrm{N}$ fertilization with Entec to sowing was not only positive because this fertilizer inibits nitrification, but also due to the low rainfall registered in the growth period

Table 3. Means and ranking regarding cultivar lodging at the maturation through visual observations

\begin{tabular}{|c|c|c|c|c|}
\hline \multirow{2}{*}{ Tratament } & \multicolumn{2}{|c|}{ E 22 Cultivar } & \multicolumn{2}{|c|}{ E 42 Cultivar } \\
\hline & Lodging & Ranking & Lodging & Ranking \\
\hline & $\%$ & & $\%$ & \\
\hline 1- Entec: $\quad 0 \mathrm{~kg} \mathrm{ha}^{-1}$ of $\mathrm{N}$ & 52.5 & $4^{(1)}$ & 0.0 & 1 \\
\hline 2- Entec: $60 \mathrm{~kg} \mathrm{ha}^{-1}$ of $\mathrm{N}$ & 57.5 & 4 & 15.0 & 2 \\
\hline 3- Entec: $120 \mathrm{~kg} \mathrm{ha}^{-1}$ of $\mathrm{N}$ & 65.0 & 4 & 40.0 & 3 \\
\hline 4- Entec: $180 \mathrm{~kg} \mathrm{ha}^{-1}$ of $\mathrm{N}$ & 60.0 & 4 & 35.0 & 3 \\
\hline 5- Urea: $0 \mathrm{~kg} \mathrm{ha}^{-1}$ of $\mathrm{N}$ & 40.0 & 3 & 5.0 & 1 \\
\hline 6- Urea: $60 \mathrm{~kg} \mathrm{ha}^{-1}$ of $\mathrm{N}$ & 55.0 & 4 & 5.0 & 1 \\
\hline 7- Urea: $120 \mathrm{~kg} \mathrm{ha}^{-1}$ of $\mathrm{N}$ & 47.0 & 3 & 0.0 & 1 \\
\hline 8- Urea: $180 \mathrm{~kg} \mathrm{ha}^{-1}$ of $\mathrm{N}$ & 60.0 & 4 & 18.0 & 2 \\
\hline
\end{tabular}

(1) Ranking for lodging: $1: 0$ to $5 \%$; $2: 6$ to $25 \%$; $3: 26$ to $50 \%$; $4: 51$ to $75 \%$ and 5: more than $75 \%$ lodged plants. 
(Figure 1) and because the soil of the experimental area is very loamy and fertile, well-drained and has a high organic matter content. Different $\mathrm{N}$ fertilizer sources have been compared by many authors (Cantarella \& Raij, 1986, Cantarella et al., 1988, Faria $\&$ Pereira, 1992), who rarely verified differences in the efficiency of these sources under field conditions, for example, regarding wheat grain yield, given satisfactory soil moisture conditions. (Bartz et al., 1976). Similarly, studies on slow-release N sources (top-dressed urea) compared with most soluble sources (urea and ammonium sulfate), did not lead to differences in rice grain yields (Magalhães \& Machado, 1973).

The hectoliter mass followed a decreasing linear function model for $\mathrm{N}$ rates. It was however observed that the wheat yield was good, since the hectoliter mass obtained in the experiment ranged from 80 to $84 \mathrm{~kg} 100 \mathrm{~L}^{-1}$, in this case, the commercialization of wheat grains is pratically guaranteed, and the return obtained by the producer will be higher, since in practice, the producer obtains a lower return when the hectoliter mass is under $78 \mathrm{~kg} 100 \mathrm{~L}^{-1}$. The grain yield followed a quadratic function model, with maximum yield when $\mathrm{N}$ application was $82 \mathrm{~kg} \mathrm{ha}^{-1}$ (Table 5).

\section{CONCLUSIONS}

1. The yield of the wheat cultivars E 21 and E 42 was highest. The ear length of $\mathrm{E} 21$ was longest, the number of spikelets per ear, grains per ear and grains per spikelet greatest and the number of undeveloped spikelets lowest.

Table 4. Mean squares, significances, overall means and coefficient of variance (\%) regarding the $\mathrm{N}$ leaf content (N LEAF), number of ears per meter (EARS/M), hectoliter mass (H. M.), mass of 100 grains (M. $100 \mathrm{G}$ ) and grain yield (G. Y.)

\begin{tabular}{|c|c|c|c|c|c|}
\hline \multirow{2}{*}{ Causes of variation } & \multicolumn{5}{|c|}{ MS } \\
\hline & N LEAF & EARS/M & H. M. & M. $100 \mathrm{G}$ & G. Y. \\
\hline Cultivar (C) & $11.791 \mathrm{~ns}$ & $2223.633^{*}$ & $528.593 * *$ & $1.834^{* *}$ & $1499454.958 * *$ \\
\hline N Sources (S) & $1283.661^{* *}$ & $21.945 \mathrm{~ns}$ & 74.741ns & $0.092 \mathrm{~ns}$ & $14818.877 \mathrm{~ns}$ \\
\hline $\mathrm{N}$ Doses (D) & $20.289 \mathrm{~ns}$ & $99.008 \mathrm{~ns}$ & $335.011^{*}$ & $0.232 \mathrm{~ns}$ & $635008.458^{* *}$ \\
\hline Blocks & $9.916 \mathrm{~ns}$ & $1436.945^{* *}$ & $276.840 \mathrm{~ns}$ & $0.092 \mathrm{~ns}$ & $211636.417 \mathrm{~ns}$ \\
\hline $\mathrm{C} \times \mathrm{S}$ & $3.188 \mathrm{~ns}$ & $11.112 \mathrm{~ns}$ & $76.154 \mathrm{~ns}$ & $0.070 \mathrm{~ns}$ & $89797.957 \mathrm{~ns}$ \\
\hline $\mathrm{C} \times \mathrm{D}$ & $7.574 \mathrm{~ns}$ & $86.174 \mathrm{~ns}$ & 92.430ns & $0.084 \mathrm{~ns}$ & $50675.961 \mathrm{~ns}$ \\
\hline $\mathrm{S} \times \mathrm{D}$ & $29.978 \mathrm{~ns}$ & $27.654 \mathrm{~ns}$ & $151.624 \mathrm{~ns}$ & $0.087 \mathrm{~ns}$ & $65419.989 \mathrm{~ns}$ \\
\hline $\mathrm{C} \times \mathrm{S} \times \mathrm{D}$ & $3.863 \mathrm{~ns}$ & $181.626 \mathrm{~ns}$ & $121.032 \mathrm{~ns}$ & $0.069 \mathrm{~ns}$ & $47818.636 \mathrm{~ns}$ \\
\hline Residue & 9.717 & 134.961 & 112.837 & 0.093 & 139322.679 \\
\hline Overall means & 43.45 & 68.95 & 81.98 & 3.70 & 3600.38 \\
\hline CV (\%) & 7.17 & 16.85 & 5.18 & 8.24 & 10.37 \\
\hline
\end{tabular}

**: significant $\mathrm{p}<0.01 ; *$ : significant $0.01<\mathrm{p}<0.05 ;$ ns: not significant.

Table 5. Means, Tukey test and regression equations for the $\mathrm{N}$ leaf content ( $\mathrm{NEAF}$ ), number of ears per meter (EARS/M), hectoliter mass (H. M.), mass of 100 grains (M. 100 G) and grain yield (G.Y.)

\begin{tabular}{|c|c|c|c|c|c|}
\hline & N LEAF & EARS/M & H. M. & M. $100 \mathrm{G}$ & G. Y. \\
\hline & $\mathrm{g} \mathrm{kg}-1^{-1}$ & & $\operatorname{kg} 100 \mathrm{~L}^{-1}$ & $\mathrm{~g}$ & $\mathrm{~kg} \mathrm{ha} \mathrm{h}^{-1}$ \\
\hline Cultivars - E 21 & $44.23 \mathrm{a}$ & $73.78 \mathrm{a}$ & $80.14 \mathrm{~b}$ & $3.46 \mathrm{c}$ & $3843 \mathrm{a}$ \\
\hline E 22 & $43.40 \mathrm{a}$ & $78.78 \mathrm{a}$ & $84.10 \mathrm{a}$ & $4.01 \mathrm{a}$ & $3460 \mathrm{~b}$ \\
\hline E 42 & $42.74 \mathrm{a}$ & $61.38 \mathrm{~b}$ & $81.89 \mathrm{ab}$ & $3.56 \mathrm{bc}$ & $3716 \mathrm{a}$ \\
\hline IAC 370 & $43.44 \mathrm{a}$ & $62.44 \mathrm{~b}$ & $81.78 \mathrm{ab}$ & $3.76 \mathrm{~b}$ & $3380 \mathrm{~b}$ \\
\hline N Sources- Entec & $40.29 \mathrm{a}$ & $68.53 \mathrm{a}$ & $81.67 \mathrm{a}$ & $3.67 \mathrm{a}$ & $3611 \mathrm{a}$ \\
\hline Urea & $46.62 \mathrm{~b}$ & $69.36 \mathrm{a}$ & $82.28 \mathrm{a}$ & $3.72 \mathrm{a}$ & 3589 a \\
\hline N Doses - 0 & 43.81 & 66.59 & $83.11^{(1)}$ & 3.79 & $3515^{(2)}$ \\
\hline$\left(\mathrm{kg} \mathrm{ha}^{-1}\right) 60$ & 44.08 & 68.69 & 82.28 & 3.67 & 3775 \\
\hline 120 & 42.29 & 69.88 & 82.40 & 3.74 & 3649 \\
\hline 180 & 43.64 & 70.63 & 80.20 & 3.59 & 3461 \\
\hline
\end{tabular}

$\overline{(1)} \hat{\mathrm{y}}=208.2690-0.0370^{* *} \mathrm{x}\left(\mathrm{R}^{2}=0.78\right) .{ }^{(2)} \hat{\mathrm{y}}=3531.4554+5.1196 \mathrm{x}-0.0311^{* *} \mathrm{x}^{2}\left(\mathrm{R}^{2}=0.91\right.$ and maximum G.Y. $=82 \mathrm{~kg}$ ha ${ }^{-1}$ of $\mathrm{N})$. ${ }^{(3)}$ Means followed by the same letter, in the column, do not differ in the Tukey test, at $5 \%$. $* *$ significant $\mathrm{p}<0.01$. 
2. The plants of cultivar $\mathrm{E} 22$ were tallest and the lodging index highest; consequently, the yields were lowest.

3. There was no significant difference between Entec (applied at sowing) and urea (topdressed) for grain yield and yield components. Nevertheless, urea resulted in higher $\mathrm{N}$ leaf contents, and Entec induced a larger number of undeveloped spikelets.

4. Higher $\mathrm{N}$ rates decreased the hectoliter mass, greatly affecting the wheat grain quality.

5. Nincreased grain yields up to a rate of $82 \mathrm{~kg} \mathrm{ha}^{-1}$ of N, using Entec applied at sowing or topdressed urea.

\section{LITERATURE CITED}

BARTZ, H.R.; SIQUEIRA, O.J.F. \& SCHOLLES, D Comparação de doses e épocas de aplicação de nitrogênio na competição de fontes de nitrogênio com diferentes solubilidades. In: REUNIÃO ANUAL CONJUNTA DE PESQUISA DE TRIGO, 8., Ponta Grossa, 1976. Anais... Solos e técnicas culturais. Passo Fundo, Embrapa-CNPT, 1976. v.2. p.1-8.

BREDEMEIER, C. \& MUNDSTOCK, C.M. Estádios fenológicos do trigo para a adubação nitrogenada em cobertura. $R$. Bras. Ci. Solo, 25:317-323, 2001

CANTARELLA, H.; SILVA, M.M.; ESPIRONELLO, A.; FURNALI, P.R.; WUTKE, A.C.P.; TOLEDO, S.V.; GALLO, P.B.; VILLELA, O.V.; QUAGGIO, J.A. \& BERTON, R.S. Avaliação agronômica de fertilizantes nitrogenados. In: GOEDERT, W.J. \& DIAS, F.A. Relatório bienal 1986-1987. Brasília, Embrapa/Petrobrás, 1988. p.33-48.

CANTARELLA, H.; RAIJ, B.van \& CAMARGO, C.E.O Cereais. In: RAIJ, B.van; CANTARELLA, H.; QUAGGIO, J.A. \& FURLANI, A.M.C. Recomendações de calagem e adubação para o Estado de São Paulo. Campinas, Instituto Agronômico de Campinas, 1997. 285p. (Boletim Técnico, 100)

CANTARELla, H.; ROSSETO, R.; BARBOSA, W.; PENNA, M.J. \& RESENDE, L.C.L. Perdas de nitrogênio por volatilização da amônia e resposta da cana-de-açúcar à adubação nitrogenada, em sistema de colheita de cana sem queima prévia. In: CONGRESSO NACIONAL DA STAB: Álcool subprodutos, 7., 1999, Londrina. Anais... Londrina, Embrapa, 1999. p.82-87.

CANTARELLA, H. \& RAIJ, B.van. Adubação nitrogenada no estado de São Paulo. In: SANTANA, M.B.M. Adubação nitrogenada no Brasil. Ilhéus, CEPLAC/SBCS, 1986. p.4779.

COQUEIRO, E.P.; SANTOS, H.L. \& ANDRADE, J.M.V. Adubação N P K e microelementos em trigo em solo de várzea, em Sete Lagoas. Pesq. Agropec. Bras., 7:111-114, 1972 .

CRUZ, P.J.; CARVALHO, F.I.F. \& CAETANO, V.R. Efeito do acamamento induzido em trigo. R. Bras. Agroci., 6:112 114,2000
EMPRESA BRASILEIRA DE PESQUISA AGROPECUÁRIA EMBRAPA. Sistema brasileiro de classificação de solos. 2.ed. Rio de Janeiro, 2006. 306p.

FARIA, C.M.B. \& PEREIRA, J.R. Fontes e níveis de nitrogênio na produtividade de cebola no submédio São Francisco. Pesq. Agropec. Bras., 27:403-407, 1992.

FREITAS, J.G.; CAMARGO, C.E.O.; PEREIRA FILHO, A.W.P \& PETTINELLI JUNIOR, A. Produtividade e resposta de genótipos de trigo ao nitrogênio. Bragantia, 53:281-290, 1994.

FREITAS, J.G.; CAMARGO, C.E.O.; PEREIRA FILHO, A.W.P. \& CASTRO, J.L. Eficiência e resposta de genótipos de trigo ao nitrogênio. R. Bras. Ci. Solo, 19:229-234, 1995.

KOELLIKER, J.K. \& KISSEL, D.E. Chemical equilibrium affecting ammonia volatilization. In: BOCK, B.R. \& KISSEL, D.E., eds. Ammonia volatilization from urea fertilizers. Muscle Shoals, Tennessee Valley Authority, National Fertilizer Development Center, 1988. p.37-52.

LOS FERTILIZANTES Y SU USO. 4.ed. Roma, FAO/IFA, 2002. p.87. Available at: <www.fertilizer.org $>$. Accessed on: Sept 5, 2006.

MAGALHÃES, A.F. \& MACHADO, C.P. Eficiência agronômica de diferentes fertilizantes nitrogenados em solos com arroz irrigado. Agron. Sulriograndense, 9:105-112, 1973.

PETTINELLI NETO, A.; CRUSCIOL, C.A.C.; BICUDO, S.J.; FREITAS, J.G. \& PULZ, A.L. Eficiência e resposta de genótipos de trigo irrigado ao nitrogênio para o Estado de São Paulo. In: CONGRESSO DE INICIAÇÃO CIENTÍFICA, 14., Presidente Prudente, 2002. Anais. Presidente Prudente, Universidade Estadual de São Paulo, 2002.CD ROM.

POTTKER, D.; FABRÍCIO, A.C. \& NAKAYAMA, L.H.I. Doses e métodos de aplicação de nitrogênio para a cultura do trigo. Pesq. Agropec. Bras., 19:1197-1201, 1984.

RAIJ, B. VAN \& QUAGGIO, J.A. Métodos de análise de solo para fins de fertilidade. Campinas: IAC, p.11-31, 1983. (Boletim Técnico Instituto Agronômico, 81)

SILVA, D.B. Efeito do nitrogênio em cobertura sobre o trigo em sucessão a soja na região dos cerrados. Pesq. Agropec. Bras., 26:1387-1392, 1991

SILVA, D.B. \& GOTO, W.S. Resposta do trigo de sequeiro ao nitrogênio, após soja precoce, na região do alto Paranaíba, MG. Pesq. Agropec. Bras., 26:1401-1405, 1991.

SOARES SOBRINHO, J. Efeito de doses de nitrogênio e de lâminas de água sobre as características agronômicas e industriais em duas cultivares de trigo (Triticum aestivum L.). Jaboticabal, Universidade Estadual Paulista, 1999. 102p. (Tese de Doutorado)

TEIXEIRA FILHO, M.C.M.; BUZETTI, S.; ALVAREZ, R.C.F.; FREITAS, J.G.; ARF, O. \& SÁ, M.E. Resposta de cultivares de trigo irrigado por aspersão ao nitrogênio em cobertura na região do Cerrado. Acta Sci. Agron., 29:421-425, 2007. 
VIEIRA, R.D.; FORNASIERI FILHO, D.; MINOHARA, L. \& BERGAMASCHI, M.C.M. Efeito de doses e de épocas de aplicação de nitrogênio em cobertura na produção e na qualidade fisiológica de sementes de trigo. Científica, 23:257-264, 1995.
ZAGONEL, J.; VENANCIO, W.S.; KUNZ, R.P. \& TANAMATI, H. Doses de nitrogênio e densidade de plantas com e sem um regulador de crescimento afetando o trigo, cultivar OR-1. Ci. Rural, 32:25-29, 2002. 